\title{
Short-Chain Fatty Acid Receptor and Its Contribution to Glucagon-Like Peptide-1 Release
}

\author{
Izumi Kaji $^{a}$ b Shin-ichiro Karaki ${ }^{b}$ Atsukazu Kuwahara ${ }^{b}$ \\ a Laboratory of Histology and Cytology, Graduate School of Medicine, Hokkaido University, Sapporo, and \\ ${ }^{b}$ Laboratory of Physiology, Institute for Environmental Sciences, University of Shizuoka, Shizuoka, Japan
}

\section{Key Words}

Luminal chemosensing - Short-chain fatty acid receptor . Enteroendocrine L cell · Glucagon-like peptide-1

\begin{abstract}
Background: Gut microbiota affects host homeostasis and dysbiosis causes host diseases. Therefore, uncovering the sensing mechanism of bacterial metabolites such as shortchain fatty acid (SCFA) may help us to understand the hostmicrobiota interaction both in physiological and nonphysiological conditions. Summary: The colonic lumen is continually exposed to many kinds of chemicals, including beneficial and harmful compounds that are produced by gut microbiota in addition to ingested nutrients. In the mammalian coIon SCFAs such as acetate, propionate and butyrate are produced by bacterial fermentation and reach about $100 \mathrm{~mm}$ under physiological conditions. In this decade, SCFA receptor genes and their expression in the intestine have been identified as free fatty acid receptor (FFA)2 and FFA3. The FFAs are located in colonic enteroendocrine $L$ cells producing and releasing an insulinotropic hormone, glucagon-like peptide-1 (GLP-1), and an anorectic hormone, peptide YY. Recent in vivo and in vitro studies suggest that SCFAs stimulate gut hormone secretion. Therefore, the SCFA-FFA signal is likely to be important for gut physiological functions. Key Message: Colonic epithelial cells express chemical receptors that detect the luminal contents, particularly bacterial metabolites, and may be involved in the host's energy metabolism via GLP-1 release, as well as the mucosal defense system.
\end{abstract}

(c) 2014 S. Karger AG, Basel

\section{KARGER}

(c) 2014 S. Karger AG, Basel

0012-2823/14/0891-0031\$39.50/0

E-Mail karger@karger.com

www.karger.com/dig

\section{Introduction}

The gut lumen is open to the external environment and it has approximately 100 trillion archaeal and bacterial cells. This means that gut microbiota contains a huge amount of genetic information; it is estimated to contain 100 - to 400 -fold more genes than the human genome. From this genetic point of view, gut microbiota has a large capacity to produce various kinds of metabolites controlled by their genes. The bacterial products include beneficial and harmful compounds for the host and affect many aspects of the host's condition. Indeed, microbiota dysfunction is linked to a variety of disorders, namely obesity, type 1 and type 2 diabetes, irritable bowel syndrome, colonic cancer, inflammatory bowel disease and abnormal immune response [1]. Furthermore, the integral role of gut microbiota in the regulation of the host's energy metabolism has also been indicated. However, mechanistic insights are obscure, and it is still unknown whether dysbiosis has a causal role in the pathogenesis of the above-mentioned diseases.

Since intestinal epithelia function as 'sentinel' to recognize beneficial or harmful compounds for the internal environment, the epithelia form a heterologous barrier sheet between the internal and luminal (external) environments. In cooperation with the epithelial sheet - consisting of absorptive, goblet, $\mathrm{M}$, enteroendocrine and brush cells - lamina propria cells and nerve fibers, which lie close to the epithelial cells but lack direct contact with the lumen, act together to balance nutrient absorption

Atsukazu Kuwahara

Laboratory of Physiology

Institute for Environmental Scinences, University of Shizuoka

Shizuoka 422-8526 (Japan)

kuwahara@u-shizuoka-ken.ac.jp 
and host-defense activities. Recent membrane receptor characterization indicates that enteroendocrine cells in particular serve important roles as sensors both in local and systemic signal transductions through gut hormone releases. One type of enteroendocrine cell is the L cell, which produces and releases glucagon-like peptide-1 (GLP-1) and peptide YY (PYY). Since GLP-1 is an insulinotropic gut hormone and PYY is an anorectic gut hormone, they are implicated in systemic energy metabolism and metabolic dysfunction. In addition, $\mathrm{L}$ cells are relatively concentrated in the terminal ileum and colon. While chemosensory mechanisms in the small intestine are well studied in conjunction with nutrient absorption, much less is known about this in the large intestine. In the mammalian colon, short-chain fatty acids (SCFAs) are present at high concentration due to bacterial fermentation and stimulate a variety of gut functions. Therefore, SCFA is considered to be one of the chemical mediators to link luminal information between microbiota and the host through SCFA receptors located in the intestinal epithelia. This mini review will focus on new information about SCFA receptors and their possible role in GLP-1 secretion in the colon.

\section{SCFA Sensing in the Colon}

As an important energy source for colonocytes, SCFA is detected and implicated in colonic homeostasis. In nonruminant mammals, SCFAs are produced by microbiota in the distal small intestine and colon from lowdigestible carbohydrates, including resistant starch and soluble oligo- and poly-saccharides. The main components of SCFAs in the human colon are acetate (2-carbon), propionate (3-carbon) and butyrate (4-carbon), at a ratio of about 3:1:1 [2]. Once produced, about $90 \%$ of SCFAs are readily absorbed by colonocytes; butyrate in particular is almost entirely utilized by colonocytes [3]. Absorbed propionate is primarily removed from the portal vein by the liver [4]. Peripheral blood levels of butyrate and propionate are therefore low under physiological conditions at 1-3 $\mu \mathrm{M}$ butyrate and $4-5 \mu \mathrm{M}$ propionate. Acetate, however, passes more freely into the peripheral circulation and shows high plasma levels of up to 100$150 \mu \mathrm{M}$ [5], and this concentration can be increased up to $250 \%(250-400 \mu \mathrm{M})$ following the hepatic breakdown of ingested ethanol [6]. On the other hand, a much higher concentration of SCFAs is present in the lumen of the nonruminant mammalian colon; the concentration volatiles depending upon bacterial activity, but it is usually about $100 \mathrm{~mm}$ [4]. Therefore, in addition to an instant energy source, SCFAs have been proposed as key signaling molecules in local and remote physiological functions such as transepithelial anion secretion, intestinal motility and systemic energy metabolism. In 1988, Yajima [7] reported the effect of SCFAs on rat colonic secretion using the Üssing chamber technique. Luminal, but not basolateral application of butyrate or propionate induces transient $\mathrm{Cl}^{-}$secretion into the lumen through the $\mathrm{G}_{\mathrm{q} / 11}$ and cholinergic pathway even in the muscleand submucosa-stripped mucosa preparations [8]. The results indicate the presence of certain sensory devices in the luminal side.

In 2003, the G protein-coupled receptors, GPR43 and GPR41, were deorphanized as receptors for SCFAs [911], and have since been renamed as free fatty acid receptor (FFA) 2 and FFA3, respectively [12] (table 1). Acetate preferentially activates human FFA2 in vitro, propionate is an even agonist for FFA2 and FFA3 and butyrate preferentially activates FFA3. However, mice FFA2 and FFA3 showed a slightly different nature - both of them responded to acetate and butyrate at the same level, but FFA3 was more sensitive to propionate than FFA2 [13], suggesting the species heterogeneity in the ligand potency for FFAs. The activation of these receptors affects distinct functions depending on the cell types expressing the receptors. For example, SCFAs suppress inflammation through FFA2 signaling in immune cells, such as neutrophil, and modulate the secretion of GLP-1 - which improves insulin secretion and has an antidiabetic effect by enteroendocrine L cells in the distal small intestine and colon [14]. Whilst the two receptors share endogenous ligands, their G-protein signaling mechanisms differ from each other. FFA2 and FFA3 can both signal through the pertussis toxin-sensitive $\mathrm{G}_{\mathrm{i} / \mathrm{o}}$ pathway, whilst FFA2 possesses the ability to signal through the $G_{q / 11}$ pathway. The physiological significance of this dual-coupling mechanism in FFA2 is not yet understood. Messenger RNA (mRNA) for FFA2 was detected in the extracts from separated mucosa of rat distal ileum and colon [15]. In human ascending colon, mRNA for FFA2 was also detected in the extracts from separated mucosa, but not from the submucosa and muscle layer [16]. These results indicate that FFA2 is expressed by colonic mucosa, but not by enteric neurons or smooth muscle cells. Since mRNA expression of FFA2 was abundant compared with FFA3 in all parts of the rat large intestine [8], FFA2- $\mathrm{G}_{\mathrm{q} / 11}$ signaling is likely to be a predominant pathway in colonic secretion. Until 2009, there was no report of FFA3 expression in the gut. Recently, we found that 
Table 1. Fatty acid receptors

\begin{tabular}{|c|c|c|c|c|c|}
\hline $\begin{array}{l}\text { Nomen- } \\
\text { clatures }\end{array}$ & $\begin{array}{l}\text { Other } \\
\text { names }\end{array}$ & G proteins & Effectors & Organic agonists & Major expression cells \\
\hline FFA1 & GPR40 & $\begin{array}{l}\mathrm{G}_{\mathrm{q} / 11} \\
\mathrm{G}_{\mathrm{s}}, \mathrm{G}_{\mathrm{i} / \mathrm{o}}\end{array}$ & $\begin{array}{l}\mathrm{Ca}^{2+} \uparrow \\
\mathrm{cAMP} \uparrow\end{array}$ & $\begin{array}{l}\text { Medium- to long-chain fatty acids, saturated } \\
\text { (C10-C18)/unsaturated (C18-C22) }\end{array}$ & $\begin{array}{l}\text { Pancreatic } \beta \text { cells } \\
\text { Enteroendocrine K cells }\end{array}$ \\
\hline FFA2 & GPR43 & $\begin{array}{l}\mathrm{G}_{\mathrm{i} / \mathrm{o}} \\
\mathrm{G}_{\mathrm{q} / 11}\end{array}$ & $\begin{array}{l}\mathrm{cAMP} \downarrow \\
\mathrm{Ca}^{2+} \uparrow\end{array}$ & $\begin{array}{l}\text { SCFAs }(\mathrm{C} 2-\mathrm{C} 7) \\
\text { Acetate }=\text { propionate }=\text { butyrate }\end{array}$ & $\begin{array}{l}\text { Immune cells } \\
\text { Enteroendocrine L cells }\end{array}$ \\
\hline FFA3 & GPR41 & $\mathrm{G}_{\mathrm{i} / \mathrm{o}}$ & cAMP $\downarrow$ & $\begin{array}{l}\text { SCFAs }(\mathrm{C} 2-\mathrm{C} 7) \\
\text { Propionate }=\text { butyrate }>\text { acetate }\end{array}$ & $\begin{array}{l}\text { Adipocytes } \\
\text { Enteroendocrine L cells }\end{array}$ \\
\hline FFA4 & GPR120 & $\mathrm{G}_{\mathrm{q} / 11}$ & $\mathrm{Ca}^{2+} \uparrow$ & $\begin{array}{l}\text { Long-chain fatty acid, saturated (C14-C18)/ } \\
\text { unsaturated (C16-C22) }\end{array}$ & Enteroendocrine L cells \\
\hline GPR84 & & $\mathrm{G}_{\mathrm{i} / \mathrm{o}}$ & cAMP $\downarrow$ & $\begin{array}{l}\text { Medium-chain fatty acids } \\
\text { (C9-C14) }\end{array}$ & Immune cells \\
\hline GPR109A & $\begin{array}{l}\text { HM74A } \\
\text { PUMA-G }\end{array}$ & $\mathrm{G}_{\mathrm{i} / \mathrm{o}}$ & $\begin{array}{l}\mathrm{cAMP} \downarrow \\
\mathrm{Ca}^{2+} \uparrow\end{array}$ & $\begin{array}{l}\text { SCFAs }(\mathrm{C} 4-\mathrm{C} 8) \\
\text { Nicotinate }\end{array}$ & $\begin{array}{l}\text { Adipocytes } \\
\text { Macrophages } \\
\text { Intestinal epithelial cells }\end{array}$ \\
\hline
\end{tabular}

FFA3 protein and mRNA were expressed in human colonic mucosa and that the expression levels were higher in the mucosa than in the submucosa and muscle layer [17].

To identify the cellular distribution of FFA2 and FFA3 in the rat and human colon, we performed an immunohistochemical study. We demonstrated that FFA2 was expressed in rat, guinea pig and human colonic epithelial cells with particularly strong expression in PYY- and GLP-1-producing L cells $[15,16,18,19]$ (fig. 1). Immunoreactivity for FFA2 in laboratory animals showed a similar pattern to those in the human colon. FFA2-immunoreactive L cells in the colon were open-type enteroendocrine cells, which extended their cell body to the luminal surface. FFA3 was also detected in human colonic L cells [17], but it is still unclear whether these two receptors function in the same cells. FFA3-immunoreactive L cells in the human colon were also open type [17]. These morphological studies indicate that PYY- and GLP-1containing L cells expressing SCFA receptors are chemosensory cells and that activation of FFA2 and FFA 3 by luminal SCFAs may regulate PYY and/or GLP-1 secretion. However, further studies are needed to clarify the precise distribution pattern of FFA2 and FFA3 and the direct evidence that link FFAs to gut hormone secretion in situ for understanding the physiological function of these receptors.

SCFA Receptor and Its Contribution to GLP-1 Release

\section{Dietary Fiber Affects Colonic Enteroendocrine Cell Populations and FFA2 Expression through SCFA Production}

Long-term ingestion of fermentable dietary fibers increases luminal concentrations of SCFAs [20]. Therefore, we have examined whether long-term ingestion of fructooligosaccharide (FOS) affects density or expression patterns of FFAs. Dietary supplementation with FOS for 4 weeks increased the density of $L$ cells expressing FFA 2 and GLP- 1 by approximately 2 -fold in the rat proximal colon, but did not affect the fecal content or density of enterochromaffin (EC) cells producing 5-HT [19] (fig. 2). By contrast, dietary supplementation with cellulose, an insoluble dietary fiber, greatly increased fecal content and the density of EC cells in the rat colon compared with those in rats fed a fiber-free diet [21]. These findings suggest that the increase in luminal SCFA concentration induces $\mathrm{L}$ cell proliferation, and that the increase in luminal content volume induces EC cell proliferation. This is supported by the following observation that supplementation with oligofructose upregulates the expression of neurogenin 3 and NeuroD, two factors that promote differentiation of enteroendocrine cells [22]. Other studies have also reported that SCFA supply to total parenteral nutrition feeding for periods of 6-72 h increased proglucagon mRNA in rat ileum [23]. Therefore, the increase in GLP-1-containing L cells 
Fig. 1. Coexpression of FFA2 (GPR43) and GLP-1 in the human rectum. FFA2 (red) and GLP-1 (green) were double stained with specific antiserums. Nuclei were counterstained with DAPI (4,6-diamidino2-phyenylindole; blue). Colocalization appears in yellow.
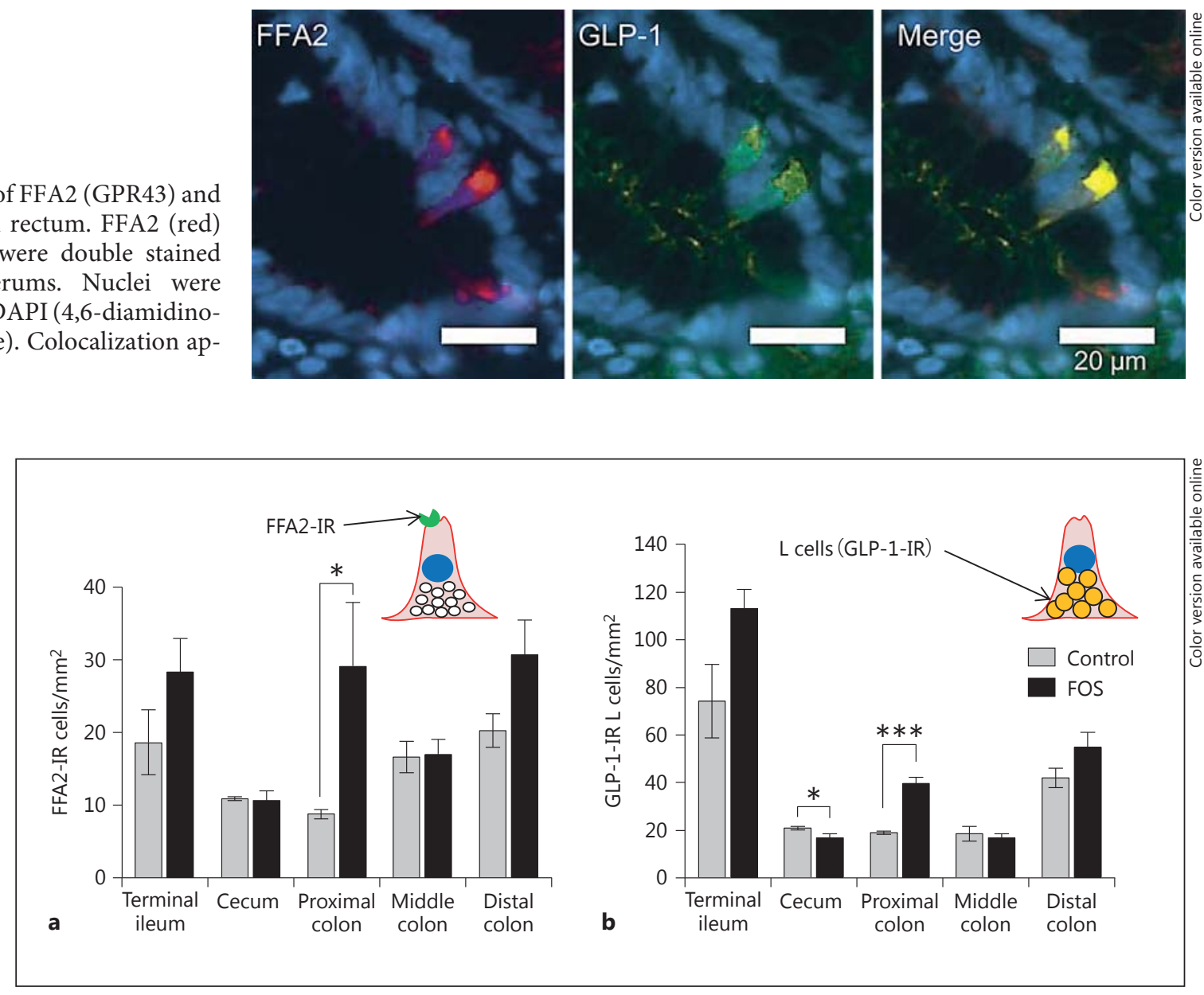

Fig. 2. Densities of FFA2- and GLP-1-immunoreactive (IR) enteroendocrine cells in the distal ileum and colon of rats fed control or FOS diets. The number of FFA2-IR (a) and GLP-1-IR (b) enteroendocrine cells per square millimeter $\left(\mathrm{mm}^{2}\right)$ of mucosa in the control (gray bars) and FOS-fed (black bars) groups were counted. The values are expressed as mean $+\mathrm{SE}(\mathrm{n}=3-4) ;^{*} \mathrm{p}<0.05$ and ${ }^{* * *} \mathrm{p}<0.001$. Modified and adapted from Kaji et al. [19].

by ingested dietary fiber would be of benefit, particularly for antiobesity, since GLP-1 reduces food intake [24].

\section{Possible Role of SCFAs in GLP-1 Secretion}

Some in vivo studies have demonstrated that intraluminal injection of SCFAs induced the release of PYY and GLP-1 into plasma $[25,26]$. Since GLP-1 secreting $\mathrm{L}$ cells are mainly located in the distal small intestine and colon, and the primary site of SCFA production is the colon, it is important to know whether luminal SCFA in the colon induces GLP-1 release into the subepithelial space in the tissue level. Therefore, we measured the
GLP-1 release response to luminal application of SCFA using an Üssing chamber. In the muscle-stripped mucosa-submucosal preparations, luminal application of $5 \mathrm{~mm}$ propionate induced GLP-1 release into the basolateral side (fig. 3). Since SCFA concentration in the colonic lumen reaches higher millimole per liter $(\mathrm{mM})$ levels, the dose of propionate in our study is in the physiological range. Consistent with these observations, the fluorescent-based cell sorting technique demonstrated that murine colonic L cells expressed both FFA2 and FFA3, and acetate and propionate increased the intracellular calcium level causing GLP-1 release via $G_{q / 11}$, but not $\mathrm{G}_{\mathrm{i}}$ [14]. The basal GLP-1 level in FFA2 knockout mice was significantly lower than in the wild-type, suggesting that FFA2 mainly contributes to GLP-1 produc- 


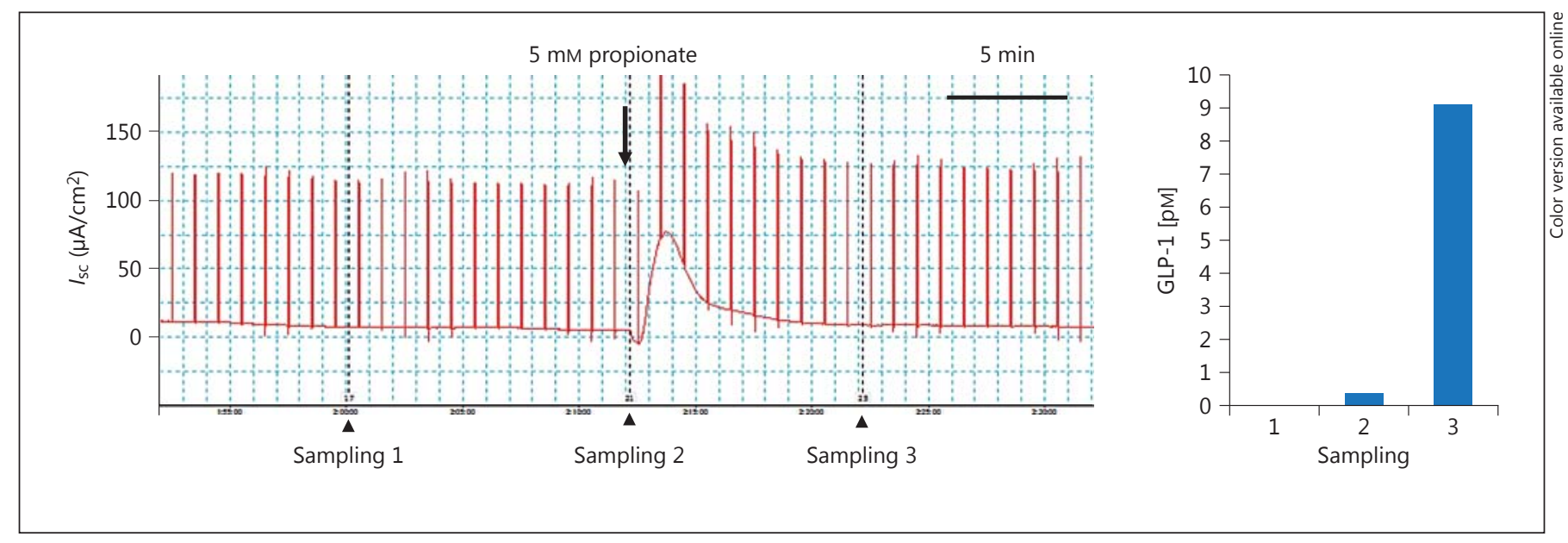

Fig. 3. Representative trace of luminal propionate-induced changes in short-circuit current $\left(I_{\mathrm{sc}}\right)$ and the release of GLP-1 into the basolateral side in the rat distal colon. Muscle-stripped mucosasubmucosa preparations from rat distal colon were mounted on an Üssing chamber. Luminal and basolateral sides were individually bathed with a physiological buffer. The luminal addition of $5 \mathrm{~mm}$ of propionate induced two-phase $I_{\text {sc }}$ responses, including negative (downward) and positive (upward) phases. Bathing solutions were collected at sampling 1-3 from the basolateral side and GLP-1 concentration was measured using enzyme-linked immunosorbent assay kits from the Yanaihara Institute (Shizuoka, Japan). tion and/or release in the murine colon [14]. On the other hand, individual FFA2- or FFA3-deficient mice showed low GLP-1 release in response to SCFAs, indicating that FFA3 is also involved in SCFA-evoked GLP1 release [14, 27]. High-dose ( $80 \mathrm{mM})$ acetate-evoked GLP-1 releases were also observed in the isolated colonic mucosa from wild-type mice, but not from a-gustducin knockout mice [28]. As gustducin is a $G_{i}$ family member, the possibility was raised that $\mathrm{G}_{\mathrm{i}}{ }^{-} \mathrm{Cou}-$ pled FFA2 and/or FFA3 elicit GLP-1 releases in the colon. Inconsistent with data from humans and rodents, none of the SCFAs (C2-C6, $5 \mathrm{mM}$ ) stimulate the release of GLP-1, GLP-2 or PYY from ileal and colonic tissues of porcine [29]. This might be caused by species differences in the ligand-binding potency of FFAs. Based on the current findings, luminal SCFAs are expected to stimulate FFA2 and/or FFA3 located on the colonic L cells and induce GLP-1 release, although the intracellular mechanism is not fully understood. As luminal SCFA concentrations are not predicted to be reduced markedly in response to acute food ingestion, it is possible that SCFAs produced by colonic bacterial fermentation provide a chronic stimulatory tone on L cells via SCFA receptors under physiological conditions. The tonic stimulation of GLP-1 secretion may chronically affect the systemic energy metabolism, because GLP-1 releases are suppressed in obese subjects [30]. If GLP-1 release could be enhanced via FFA2 and FFA3 activation, the potential for dietary or pharmacological manipulation to increase satiety could be used in the treatment of obesity in the future.

\section{Conclusion}

Since obesity and metabolic disorders are associated with changes in gut microbiota, the integral role of gut microbiota in the regulation of host energy metabolism has attracted considerable attention [31]. However, because of the complexity of the microbial community, the functional connections between dysbiosis and human diseases are less well understood. SCFAs are primary metabolites of gut microbiota and present in the colon at high concentrations. SCFA sensing in the colon serves two important functions - the energy survey and the mucosal defense against microbial pathogenicity. We have shown that the SCFA receptors FFA2 and FFA3 are located in rodent and human colonic $\mathrm{L}$ cells containing GLP-1 and PYY, suggesting that FFA2 and/or FFA3 may be implicated in the host energy metabolism through PYY and GLP-1 releases. Furthermore, we have demonstrated that luminal application of SCFA evokes GLP-1 release and that long-term ingestion of FOS influences the density of FFA2-expressing L cells. Although the re- 
lationship between gut microbiota and host energy metabolism remains controversial, recent observations suggest that the host-microbial interaction is mediated by gut hormone secretion stimulated by the receptors of a kind of bacterial product SCFA.

\section{Disclosure Statement}

The authors have no conflicts of interest to declare.

\section{References}

1 Burcelin R: Regulation of metabolism: a cross talk between gut and microbiota and its human host. Physiology 2012;27:300-307.

-2 Høverstad T, Fausa O, Bjørneklett A, Bøhmer T: Short-chain fatty acids in the normal human feces. Scan J Gastroenterol 1984;19:375381.

$\checkmark 3$ Roediger WE: Role of anaerobic bacteria in the metabolic welfare of the colonic mucosa in man. Gut 1980;21:793-798.

4 Cummings JH, Pomare EW, Branch WJ, Naylor CP, Macfarlane GT: Short chain fatty acids in human large intestine, portal, hepatic and venous blood. Gut 1987;28:1221-1227.

$\checkmark 5$ Hong YH, Nishimura Y, Hishikawa D, Tsuzuki H, Miyahara H, Gotoh C, Choi KC, Feng DD, Chen C, Lee HG, Katoh K, Roh SG, Sasaki S: Acetate and propionate short chain fatty acids stimulate adipogenesis via GPCR43. Endocrinology 2005; 146:50925099.

-6 Siler SQ, Neese RA, Hellerstein MK: De novo lipogenesis, lipid kinetics, and whole-body lipid balance in humans after acute alcohol consumption. Am J Clin Nutr 1999;70:928936.

$>7$ Yajima T: Luminal propionate-induced secretory response in the rat distal colon in vitro. J Physiol 1988;403:559-575.

$>8$ Yajima $T$, Inoue $R$, Yajima $M$, Tsuruta $T$, Karaki S, Hira T, Kuwahara A: The G-protein on cholesterol-rich membrane microdomains mediates mucosal sensing of shortchain fatty acid and secretory response in rat colon. Acta Physiol (Oxf) 2011;203:381-389.

$>9$ Brown AJ, Goldsworthy SM, Barnes AA, Eilert MM, Tcheang L, Daniels D, Muir AI, Wigglesworth MJ, Kinghorn I, Fraser NJ, Pike NB, Strum JC, Steplewski KM, Murdock PR, Holder JC, Marshall FH, Szekeres PG, Wilson S, Ignar DM, Foord SM, Wise A, Dowell SJ: The Orphan G protein-coupled receptors GPR41 and GPR43 are activated by propionate and other short chain carboxylic acids. J Biol Chem 2003;278:1131211319.

$>10$ Le Poul E, Loison C, Struyf S, Springael JY, Lannoy V, Decobecq ME, Brezillon S, Dupriez V, Vassart G, Van Damme J, Parmentier M, Detheux M: Functional characterization of human receptors for short chain fatty acids and their role in polymorphonuclear cell activation. J Biol Chem 2003;278:25481-25489.
Nilsson NE, Kotarsky K, Owman C, Olde B:
Identification of a free fatty acid receptor, FFA2R, expressed on leukocytes and activated by short-chain fatty acids. Biochem Biophys Res Commun 2003;303:1047-1052.

12 Stoddart LA, Smith NJ, Milligan G: International Union of Pharmacology. LXXI. Free fatty acid receptors FFA1, -2, and -3: pharmacology and pathophysiological functions. Pharmacol Rev 2008;60:405-417.

13 Hudson BD, Tikhonova IG, Pandey SK, Ulven T, Milligan G: Extracellular ionic locks determine variation in constitutive activity and ligand potency between species orthologs of the free fatty acid receptors FFA2 and FFA3. J Biol Chem 2012;287:41195-41209.

14 Tolhurst G, Heffron H, Lam YS, Parker HE, Habib AM, Diakogiannaki E, Cameron J, Grosse J, Reimann F, Gribble FM: Shortchain fatty acids stimulate glucagon-like peptide- 1 secretion via the G-protein-coupled receptor FFAR2. Diabetes 2012;61:364-371.

15 Karaki S, Mitsui R, Hayashi H, Kato I, Sugiya $\mathrm{H}$, Iwanaga T, Furness JB, Kuwahara A: Short-chain fatty acid receptor, GPR43, is expressed by enteroendocrine cells and mucosal mast cells in rat intestine. Cell Tissue Res 2006;324:353-360.

16 Karaki S, Tazoe H, Hayashi H, Kashiwabara H, Tooyama K, Suzuki Y, Kuwahara A: Expression of the short-chain fatty acid receptor, GPR43, in human colon. J Mol Histol 2008; 39:135-142.

17 Tazoe H, Otomo Y, Karaki S, Kato I, Fukami Y, Terasaki M, Kuwahara A: Expression of short-chain fatty acid receptor GPR41 in the human colon. Biomed Res 2009;30:149-156.

18 Karaki SI, Kuwahara A: Propionate-induced epithelial $\mathrm{K}^{+}$and $\mathrm{Cl}^{-} / \mathrm{HCO}^{-}{ }_{3}$ secretion and free fatty acid receptor 2 (FFA2, GPR43) expression in the guinea pig distal colon. Pflügers Arch 2011;461:141-152.

19 Kaji I, Karaki S, Tanaka R, Kuwahara A: Density distribution of free fatty acid receptor 2 (FFA2)-expressing and GLP-1 producing enteroendocrine L cells in human and rat lower intestine, and increased cell numbers after ingestion of fructo-oligosaccharide. J Mol Histol 2011;42:27-38.

20 Ten Bruggencate SJ, Bovee Oudenhoven IM, Lettink Wissink ML, Van der Meer R: Dietary fructooligosaccharides increase permeability in rats. J Nutr 2005; 135:837-842.
21 Mitsui R, Karaki SI, Kubo Y, Sugiura Y, Kuwahara A: Fibre-free diet leads to impairment of neuronally mediated muscle contractile response in rat distal colon. Neurogastroenterol Motil 2006;18:1093-1101.

22 Cani PD, Hoste S, Guiot Y, Delzenne NM: Dietary non-digestible carbohydrates promote L-cell differentiation in the proximal colon of rats. Br J Nutr 2007;98:32-37.

23 Drozdowski LA, Dixon WT, McBurney MI, Thomson AB: Short-chain fatty acids and total parenteral nutrition affect intestinal gene expression. JPEN Parenter Enteral Nutr 2002; 26:145-150.

24 Flint A, Raben A, Astrup A, Holst JJ: Glucagon-like peptide 1 promotes satiety and suppresses energy intake in humans. J Clin Invest 1998;101:515-520.

25 Dumoulin V, Moro F, Barcelo A, Dakka T, Cuber JC: Peptide YY, glucagon-like peptide- 1 and neurotensin response to luminal factors in the isolated vascularly perfused rat ileum. Endocrinology 1998;139:3780-3786.

26 Freeland KR, Wolever TM: Acute effects of intravenous and rectal acetate on glucagonlike peptide-1, peptide YY, ghrelin, adiponectin and tumor necrosis factor- $\alpha$. Br J Nur 2010;103:460-466.

27 Lin HV, Frassetto A, Kowalik EJ Jr, Nawrocki AR, Lu MM, Kosinski JR, Hubert JA, Szeto D, Yao X, Forrest G, Marsh DJ: Butyrate and propionate protect against diet-induced obesity and regulate gut hormones via free fatty acid receptor 3-independent mechanisms. PLoS One 2012;7:e35240.

-28 Li Y, Kokrashvili Z, Mosinger B, Margolskee RF: Gustducin couples fatty acid receptors to GLP-1 release in colon. Am J Physiol Endocrinol Metab 2013;304:E651-E660.

29 Voortman T, Hendriks HF, Witkamp RF, Wortelboer HM: Effects of long- and shortchain fatty acids on the release of gastrointestinal hormones using an ex vivo porcine intestinal tissue model. J Agric Food Chem 2012;60:9035-9042.

30 Verdich C, Toubro S, Buemann B, Madsen JL, Holst JJ, Astrup A: The role of postprandial releases of insulin and incretin hormones in meal-induced satiety - effect of obesity and weight reduction. Int J Obesity 2001;25:12061214.

-31 Arora T, Sharma R, Frost G: Propionate: antiobesity and satiety enhancing factor? Appetite 2011;56:511-515. 